\title{
New Opportunities for the Development of Corporate Governance in Power Generating Companies for the Benefit of Investors
}

\author{
G.I. Sheveleva*
}

Melentiev Energy Systems Institute of Siberian Branch of Russian Academy of Sciences, Irkutsk, Russia

\begin{abstract}
The paper presents an analysis of the central metrics of corporate governance in wholesale and territorial generating companies of the electric power industry that concern ownership structure and compliance of the companies with the principles of the Corporate Governance Code based on their performance results of 2018 - 2019. An increase in ownership concentration and the presence of the state in the competitive segment of the electric power industry is noted. This study has identified the least met criteria for evaluating compliance with the principles of the Corporate Governance Code. The possibilities of developing corporate governance for the benefit of investors are elucidated. These are tightening control over the observance of international "soft law" ("comply or explain"); expanding the criteria for evaluating compliance with the principles of the Corporate Governance Code that are recommended by the Bank of Russia; updating the Corporate Governance Code based on ESG (Environmental, Social, and Governance) transformation. A new form of oversight over compliance with the Corporate Code principles and criteria for evaluating the adherence to the ESG principles are proposed.
\end{abstract}

Index Terms: corporate governance, development, investors, ownership, power generating companies.

\footnotetext{
${ }^{*}$ Corresponding author.

E-mail: sheveleva@isem.irk.ru
}

http://dx.doi.org/10.38028/esr.2021.03.0006

Received September 15, 2021. Revised September 21, 2021.

Accepted October 03, 2021. Available online November 28, 2021.

This is an open access article under a Creative Commons Attribution-NonCommercial 4.0 International License.

(C) 2021 ESI SB RAS and authors. All rights reserved.

\section{INTRODUCTION}

Corporate governance is aimed at creating an effective system to ensure the safety of funds provided by shareholders and their efficient use. In a stage of world development, there were defined international standards (principles) of corporate governance to protect the interests of all shareholders [1]. Domestic companies assign a central guiding role in establishing these standards to the Russian Corporate Governance Code (further referred to as the Code) [2]. The search for new opportunities for its development is due to the specificity and certain contradictions of corporate governance in Russia.

The purpose of the study was to identify new opportunities for the development of corporate governance in wholesale (WGCs) and territorial (TGCs) generating companies in the electric power industry (further referred to as generating companies) for the benefit of investors. The structure of shareholders' equity and corporate governance in 2018-2019 were considered to be the major points of corporate governance practices in these companies.

The corporate governance practices were primarily analyzed according to the criteria for evaluating the observance of the Corporate Governance Code principles (further on, evaluation criteria) by these companies. As a methodology, we used the recommendations of the Bank of Russia on the preparation of reports of domestic companies «On Compliance with the Principles and Recommendations of the Corporate Governance Code» (Letter of the Bank of Russia No. IN-06-52/8 dated February 17, 2016) and the identified evaluation criteria that were not included in the Recommendations. Generating companies that published the Corporate Governance Code Compliance Annexes (2018-2019) [3-11] in their annual reports were investigated. The companies that did not post them on their official websites (Siberian Generating Company LLC, T Plus PJSC, Fortum OJSC, TGC-14 PJSC, and generating 
companies of LUKOIL PJSC) were not considered.

The data used were taken from official websites of generating companies, the Unified State Register of Legal Entities, the information agency Bigpowernews [12-14], the National Council on Corporate Governance [15-16], the international companies of PricewaterhouseCoopers [17], the AFEP-MEDEF Code of Corporate Governance of listed companies (France) [18], the UK Corporate Governance Code [19], the Italian Corporate Governance Code [20], the German Corporate Governance Code [21], the Corporate Governance Code of Sberbank PJSC [22], the Russian Institute of Directors [23], the Transition Institute [24], the results of research [25-27], and other information sources [28].

The ownership structure of generating companies was analyzed as of the end of 2019, with its concentration and main shareholders determined. The observance of the evaluation criteria recommended by the Bank of Russia by generating companies in 2018-2019 was assessed. The criteria that were the least adhered to by an overwhelming number of companies were identified as well as those not included in the recommended by the Bank of Russia. New possibilities for corporate governance development in the interests of investors were elucidated. One of them is the tightening of control over compliance with international «soft law» («comply or explain») based on the French experience. Other new possibilities concerned the inclusion of additionally identified criteria of the Code into those recommended by the Bank of Russia to assess compliance with its principles; updating the Code through the ESG
(Environmental, Social, and Corporate Governance) transformation with a proposed set of criteria to evaluate the observance of the ESG principles.

\section{CORPORATE GOVERNANCE IN GENERATING COMPANIES}

The points of corporate governance practices in power generating companies considered to be primary for the benefit of investors are

- Ownership structure.

- Compliance with the principles of the Corporate Governance Code.

These points serve as a kind of metric of corporate governance in generating companies and its further development. Ownership structure and corporate governance are closely related, but for this study, were conventionally separated.

\section{A. Ownership structure.}

The ownership structure is one of the characteristic features that united the models of corporate governance that emerged in developed countries into the so-called «AngloAmerican» and «German» models. The representatives of the «Anglo-American» model are the USA and Great Britain. This model is characterized by a dispersed shareholding structure, i.e., with the predominance of many small (minority) shareholders. The nature of ownership and voting rights under this model is dispersed since there are no large (majority) owners. Managers are vested with substantial rights, and the main conflict is that of «a weak owner - a strong manager.» Highly developed and liquid

Table 1. The major shareholders of Russian power generating companies, 2019.

\begin{tabular}{ll}
\hline \hline \multicolumn{1}{c}{ COMPANIES } & \multicolumn{1}{c}{ THE MAJOR SHAREHOLDERS AND THEIR SHARES IN SHAREHOLDERS' EQUITY, \% } \\
\hline WGC-1 OJSC & Inter RAO UES PJSC (100) \\
\hline WGC-2 PJSC & Centrenergoholding LLC (73.4) \\
\hline WGC-3 OJSC & Inter RAO UES PJSC (100) \\
\hline Unipro (WGC-4) PJSC & Uniper SE (Germany) (83.7) \\
\hline Enel Russia PJSC (WGC-5) & Enel S.p.A. (Italy) (56.4), PFR Partners Fund I Limited (Cyprus) (19.0), \\
& Prosperity Capital Management Limited (Cayman Islands)(7.7) \\
\hline RusHydro PJSC & Russian Federation (Federal Agency for State Property Management) (61.2), VTB Bank PJSC (13.1), \\
& Avitrans LLC (6.0) \\
\hline TGC-1 PJSC & Gazprom Energoholding LLC (51.8), Fortum Power and Heat Oy (Finland) (29.5) \\
\hline TGC-2 PJSC & Litim Trading Limited (British Virgin Islands - BVI) (1.5), Cores Invest LLC (9.5), Janan Holdings Limited \\
\hline Mosenergo PJSC (TGC-3) & (BVI) (14.7), Raltaka Enterprises Limited (BVI) (7.3), Dolgovoye Agentstvo LLC (27.0) \\
\hline Quadra PJSC (TGC-4) & Gazprom Energoholding LLC (53.5), Moscow City Government (26.5) \\
\hline T Plus PJSC (TGC-5, TGC-6, & ZANEXIM Group LLC (52.0), BusinessINFORM LLC (25.7) \\
TGC-7, TGC-9) & (Cyprus) (12.2), Merol Trading Limited (Cyprus) (11.7) \\
\hline Generating companies of & LUKOIL PJSC (100) \\
LUKOIL PJSC (TGC-8) & \\
\hline Fortum OJSC (TGC-10) & Fortum Russia B.V. (Finland) (69.9), Fortum Holding B.V. (28.4) \\
\hline TGC-11 OJSC & Inter RAO UES PJSC (100) \\
\hline Kuzbassenergo JSC (TGC-12) & Siberian Energy Investment Ltd (Cyprus) (100) \\
\hline Yeniseyskaya TGC (TGC-13) & Siberian Energy Investment Ltd (Cyprus) (100) \\
JSC & \\
\hline TGC-14 PJSC & Energopromsbyt LLC (39.8), TRINFICO Holdings JSC (20.6), TRANSFINGROUP Asset Management \\
\hline \hline
\end{tabular}


stock markets are the primary tool for external control and improvement of corporate governance in this model.

The «German» model of corporate governance is characteristic of Germany and some other countries of continental Europe, as well as Japan and Korea (sometimes the «Japanese» model is considered as an independent one). In this case, the shareholding structure is concentrated, with several major owners. Ownership is held by a small number of shareholders, voting rights are tied to ownership rights, and the position of minority owners and managers is weak. The conflict in this model of corporate governance is «weak managers, weak minority owners - strong majority owners.» The external corporate control under less developed market mechanisms is carried out through the parent bank.

The emerging Russian model of corporate governance does not fit into the global models at issue, in part because of the relative weakness of the domestic securities market and banking system, institutions of law, established practice in applying the law, non-competitive commodity markets, capital, and labor markets, and undeveloped enforcement. It has features of both corporate governance models at issue. It is partly «German» because of highly concentrated ownership and strong majority control by large owners. It is partly "Anglo-American» due to the basic principles of Anglo-Saxon law focused on the protection of small shareholders and the widespread adoption of American financial reporting standards, both embedded in Russian corporate governance [27]. According to the Institute for the Economy in Transition, the impossibility of direct adaptation of the Russian corporate governance model to the world models was justified, in particular, by the specific structure of the economy and the domestic legal environment [24].

The current ownership structure in WGCs and TGCs as of the end of 2019 (main shareholders and their shares in the share capital according to their official websites) is shown in Table 1.

According to the data presented in Table 1, the number of WGCs and TGCs decreased relative to those established after the liquidation of RAO UES of Russia (2008). This consolidation was caused, in particular, by the merger of TGC-12 OJSC and TGC-13 OJSC into the Siberian Generating Company Group, as well as the takeover of TGC5 OJSC, TGC-6 OJSC, and TGC-9 OJSC by Volga TGC OJSC («TGC-7»), which was renamed into T Plus PJSC in 2015. WGC-6 OJSC joined Gazprom Energoholding LLC. Further consolidation of generating companies was noted to begin. The Finnish Fortum intends to buy the Russian electric power company Unipro PJSC (a German Uniper subsidiary in Russia) [3]. Gazprom Energoholding LLC is interested in purchasing the generating companies of LUKOIL PJSC and Quadra PJSC if an agreement on the evaluation of their assets is reached [13]. Negotiations are underway to merge Gazprom Energoholding LLC with T Plus PJSC. For the time being, they have been temporarily suspended due to, among other things, the unresolved price range issues for the transaction outlined by Gazprom Energoholding LLC and the role of minority shareholders in the management of T Plus PJSC [14].

There is a steady tendency for the state to increase its presence in the shareholders' equity of generating companies, with an associated general increase in the concentration of ownership. The state from the very beginning stayed in the competitive segment of power generation when the state-owned companies FGC UES OJSC, RusHydro OJSC, Gazprom OJSC, and Russian Railways OJSC partially privatized the generating assets of WGC-1 OJSC, WGC-5 OJSC, WGC-6 OJSC, TGC-1 OJSC, TGC-3 OJSC, and TGC-14 OJSC. Inter RAO UES PJSC acquired $100 \%$ of voting shares of TGC-11JSC, reorganized WGC-1 OJSC and WGC-3 OJSC in terms of its $100 \%$ ownership of shares there, and incorporated generating assets of Bashkirenergo OJSC. In this context, the permanent increase in the share of the state-owned installed electric capacity of wholesale and territorial generating companies proves telling. In 2016, the state had a little over $55 \%$, private entrepreneurs owned $26 \%$ of the installed electric capacity of WGCs and TGCs, and foreign owners had 14\% [25]. By the end of 2019, the state's share had increased to $63.9 \%$, private entrepreneurs retained $22.5 \%$, and foreign owners $-13.6 \%$.

The concentration of ownership in generating companies with foreign owners increased from $78.1 \%$ (2009) to $83.7 \%$ (2019) in Unipro PJSC (former WGC-4 OJSC) and from $92.9 \%$ (2009) to $98.3 \%$ in Fortum OJSC (TGC-10 OJSC) (2019).

The concentration of ownership in generating companies owned by private Russian entrepreneurs has increased. The generating assets of Southern Generation Company - WGC-8 were transferred to LUKOIL PJSC (V. Alekperov). The merger of Kuzbassenergo JSC (former TGC-12 OJSC) and Yeniseyskaya TGC JSC (former TGC13 OJSC) into the Siberian Generating Company increased the concentration of ownership owned by A. Melnichenko. V. Vekselberg established a new generating company T Plus PJSC, which consolidated the assets of TGC-5 OJSC, TGC-6 OJSC, TGC-9 OJSC, and TGC-7 OJSC. The majority shareholders L. Lebedev (TGC-2 OJSC) and M. Prokhorov (Quadra PJSC) increased the concentration of their ownership in these companies through their affiliated and controlled structures. Cores Invest LLC, foreign offshore companies Janan Holdings Limited, Raltaka Enterprises Limited, and Litim Trading Limited, represented among the major shareholders of TGC-2 OJSC, are affiliated with L. Lebedev. TGC-2 OJSC was also a founder of one of the main shareholders of this company, Dolgovoye Agentstvo LLC (Data from the Unified State Register of Legal Entities). M. Prokhorov controlled the main shareholders of Quadra PJSC (ONEXIM Group LLC and BusinessINFORM LLC) (see Table 1).

As a result of the permanent redistribution of ownership 
and the increase in the state's share in generating companies with state participation, investors are exposed to increasing risks that the state can use its influence to promote state social and strategic programs at the expense of the companies' shareholder value. This is partly a consequence of the systematic confusion of the functions of the state as regulator and shareholder, obviously contradicting the basic OECD principle of corporate governance for companies with state participation, which separates these functions. Additional investment risks are possible when the interests of certain groups of shareholders are behind the state's influence on public companies.
As the state's proportion in the ownership of generating companies increases, the number of board of directors members and CEOs from the former government employees tends to grow. There is a practice of sending directives to board members to vote on the most crucial issues (appointment/dismissal of CEO and approval of the CEO contract, approval of the strategy, amendments to some internal documents, approval of the value of dividends, and others). The number of issues on which voting directives are sent is steadily expanding. The authors of the draft resolutions included in the directives are usually not known. There is no practice of preliminary

Table 2. Compliance with the Code Criteria (the case study of WGC-2 PJSC), 2018-2019.

\begin{tabular}{|c|c|c|c|c|c|c|c|c|}
\hline \multirow[b]{3}{*}{ 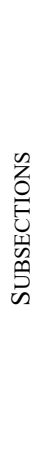 } & \multirow[b]{3}{*}{ 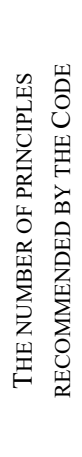 } & \multirow{3}{*}{ 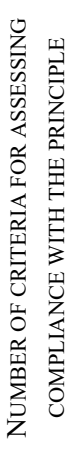 } & \multicolumn{6}{|c|}{ STATUS OF COMPLIANCE WITH THE EVALUATION CRITERIA } \\
\hline & & & \multicolumn{3}{|c|}{2018} & \multicolumn{3}{|c|}{2019} \\
\hline & & & 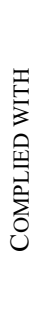 & 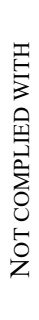 & 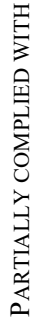 & 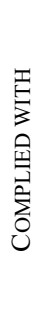 & 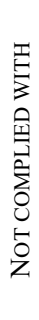 & 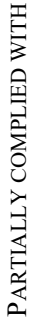 \\
\hline
\end{tabular}

\begin{tabular}{|c|c|c|c|c|c|c|c|c|}
\hline \multicolumn{9}{|c|}{ I. Rights of shareholders and equal conditions for shareholders in exercising their rights } \\
\hline 1.1. & 6 & 14 & 12 & - & 2 & 12 & - & 2 \\
\hline 1.2 . & 4 & 5 & 3 & 1 & 1 & 3 & 1 & 1 \\
\hline 1.3 . & 2 & 2 & 2 & - & - & 2 & - & - \\
\hline 1.4. & 1 & 1 & 1 & - & - & 1 & - & - \\
\hline \multicolumn{9}{|c|}{ II. Board of directors } \\
\hline 2.1. & 7 & 12 & 9 & 1 & 2 & 10 & - & 2 \\
\hline 2.2 & 2 & 3 & 2 & 1 & - & 2 & 1 & 1 \\
\hline 2.3 & 4 & 5 & - & 2 & 3 & - & 3 & 2 \\
\hline 2.4 . & 4 & 6 & 3 & 2 & 1 & 4 & 2 & - \\
\hline 2.5 & 3 & 4 & 2 & 2 & - & 2 & 2 & - \\
\hline 2.6 . & 4 & 8 & 4 & 2 & 2 & 3 & 1 & 4 \\
\hline 2.7 & 4 & 4 & 3 & 1 & - & 2 & - & 2 \\
\hline 2.8 . & 6 & 13 & 4 & 2 & 7 & 4 & 1 & 8 \\
\hline 2.9. & 2 & 3 & 2 & 1 & - & - & 3 & - \\
\hline \multicolumn{9}{|c|}{ III. Corporate Secretary } \\
\hline 3.1 . & 2 & 3 & 3 & - & - & 3 & - & - \\
\hline \multicolumn{9}{|c|}{ IV. Remuneration system for members of the board of directors, executive bodies, and other key executives } \\
\hline 4.1 . & 4 & 4 & 3 & 1 & - & 3 & 1 & - \\
\hline 4.2 . & 3 & 3 & 1 & 1 & 1 & 2 & - & 1 \\
\hline 4.3 . & 3 & 6 & 3 & 3 & - & 3 & 3 & - \\
\hline \multicolumn{9}{|c|}{ V. Risk management and internal control system } \\
\hline 5.1. & 4 & 5 & 4 & 1 & - & 3 & 1 & 1 \\
\hline 5.2 . & 2 & 3 & 2 & - & 1 & 3 & - & - \\
\hline \multicolumn{9}{|c|}{ VI. Information disclosure, information policy } \\
\hline 6.1 & 2 & 5 & 4 & 1 & - & 3 & 1 & 1 \\
\hline 6.2 & 3 & 7 & 7 & - & - & 7 & - & - \\
\hline 6.3 & 2 & 3 & 3 & - & - & 3 & - & - \\
\hline \multicolumn{9}{|c|}{ VII. Material corporate actions } \\
\hline 7.1 . & 3 & 5 & 4 & 1 & - & 4 & - & 1 \\
\hline 7.2 . & 2 & 4 & 3 & 1 & - & 3 & 1 & - \\
\hline Total & 79 & 128 & 84 & 24 & 20 & 81 & 21 & 26 \\
\hline
\end{tabular}


discussion of these projects by board members. There is virtually no voting against draft resolutions proposed in the directives since board members who do not vote «for» can, among other things, be excluded from candidates at the next nomination. This practice of voting by directives negatively affects the decision-making of independent directors, ultimately distorting the entire institution of independent directors and harming other shareholders. Former officials as independent directors are no longer responsible for the company's standing but serve only the interests of the state $[23,25,28]$.

In foreign practice, companies with state participation restrict and even prohibit the election of ministers, secretaries of state, and other high-ranking government officials to the boards of directors. This practice helps prevent conflicts of interests among politicians, regulators, and other shareholders. Such restrictions are necessary for generating companies with state participation to avoid lobbying (through state officials on boards of directors with regulatory powers) of management interests and giving state companies preferential treatment over private companies [23].

In the emerging environment, measures are needed to strengthen generating companies' observance of the corporate governance principles for the benefit of investors. Such principles are meant to ensure the safety of funds provided by the investors and their efficient use, thus reducing the risks that investors cannot assess.

\section{B. Compliance with the principles of the Corporate} Governance Code.

Corporate practice in any of the world models follows international principles. These principles are recognized worldwide, including in developing countries and countries in transition that are interested in attracting investment. They emerged from the generalization of data on corporate governance of the states of the Organization for Economic Cooperation and Development («Principles of Corporate Governance of the OECD») [1]. In this paper, they are given below in an updated (after their revision in 20142015) and slightly aggregated form:
- The corporate governance structure shall encourage transparent and fair markets and efficient resource allocation, comply with the rule by law, and support effective oversight and enforcement.

- The corporate governance structure shall protect the rights and ensure fair and equal treatment of all shareholders. All shareholders shall have the opportunity to be compensated for the violation of their rights.

- The corporate governance infrastructure shall provide thorough incentives and prescribe that securities markets function in a way that promotes good corporate governance development.

- The corporate governance structure shall recognize the rights of stakeholders, as provided by law or in multilateral agreements and encourage active cooperation between corporations and stakeholders.

- The corporate governance infrastructure shall ensure timely and accurate disclosure of information on all material matters related to the corporation, including the financial standing, results of operations, ownership, and management of a company.

- The corporate governance structure shall provide for the strategic guidance of the company, effective control over management by the boards of directors, and accountability of the boards of directors to the company and shareholders.

- These international principles of corporate governance, given domestic specifics, formed the basis of the Russian Corporate Governance Code developed in 2014. After some generalization consistent with the Bank of Russia's recommendations for reporting on «Compliance with the Principles and Recommendations of the Corporate Governance Code» in the annual reports of Russian companies, the principles of the Russian Code are listed below [2].

- Observance of shareholders' rights to participate in the management and profits of companies, ensuring equal conditions for their exercise, reliability, and efficiency of accounting for shareholders' rights to their shares.

- Effectiveness and professional competence of the

Table 3. Generating companies' compliance with Code criteria, 2018-2019.

\begin{tabular}{|c|c|c|c|c|c|c|c|c|c|c|c|c|}
\hline \multirow{4}{*}{$\begin{array}{c}\text { Companies } \\
\text { (PJSC) }\end{array}$} & \multirow{2}{*}{\multicolumn{4}{|c|}{ COMPLIED WITH }} & \multirow{2}{*}{\multicolumn{4}{|c|}{$\begin{array}{c}\text { PARTIALLY } \\
\text { COMPLIED WITH }\end{array}$}} & \multirow{2}{*}{\multicolumn{4}{|c|}{ NOT COMPLIED WITH }} \\
\hline & & & & & & & & & & & & \\
\hline & \multicolumn{2}{|c|}{2019} & \multicolumn{2}{|c|}{2018} & \multicolumn{2}{|c|}{2019} & \multicolumn{2}{|c|}{2018} & \multicolumn{2}{|c|}{2019} & \multicolumn{2}{|c|}{2018} \\
\hline & Number & $\%$ & Number & $\%$ & Number & $\%$ & Number & $\%$ & Number & $\%$ & Number & $\%$ \\
\hline Inter RAO & 124 & 96.8 & 125 & 97.6 & 2 & 1.6 & 2 & 1.6 & 2 & 1.6 & 1 & 0.8 \\
\hline Enel Russia & 120 & 93.8 & 120 & 93.8 & 5 & 3.9 & 5 & 3.9 & 3 & 2.3 & 3 & 2.3 \\
\hline TGC-1 & 81 & 63.3 & 89 & 69.4 & 27 & 21.1 & 37 & 28.0 & 20 & 15.6 & 2 & 1.6 \\
\hline RusHydro & 123 & 96.1 & 123 & 96.1 & 3 & 2.3 & 2 & 1.6 & 2 & 1.6 & 3 & 2.3 \\
\hline Unipro & 102 & 79.7 & 98 & 76.5 & 16 & 12.5 & 18 & 14.1 & 10 & 7.8 & 12 & 9.4 \\
\hline WGC-2 & 81 & 63.3 & 84 & 65.6 & 26 & 20.3 & 20 & 15.6 & 21 & 16.4 & 24 & 18.8 \\
\hline Mosenergo & 78 & 61.0 & 62 & 48.4 & 30 & 23.4 & 56 & 43.8 & 20 & 15.6 & 10 & 7.8 \\
\hline Quadra & 76 & 59.4 & 75 & 58.6 & 22 & 17.2 & 22 & 17.2 & 30 & 23.4 & 31 & 24.2 \\
\hline TGC-2 & 80 & 62.5 & 58 & 45.3 & 36 & 28.1 & 37 & 28.9 & 12 & 19.4 & 33 & 25.8 \\
\hline
\end{tabular}


Table 3. Generating companies' compliance with Code criteria, 2018-2019.

\begin{tabular}{|c|c|c|c|c|c|c|c|c|c|c|c|c|}
\hline \multirow{4}{*}{$\begin{array}{c}\text { Companies } \\
\text { (PJSC) }\end{array}$} & \multicolumn{4}{|c|}{ COMPLIED WITH } & \multirow{2}{*}{\multicolumn{4}{|c|}{$\begin{array}{c}\text { PARTIALLY } \\
\text { COMPLIED WITH }\end{array}$}} & \multirow{2}{*}{\multicolumn{4}{|c|}{ NOT COMPLIED WITH }} \\
\hline & & & & & & & & & & & & \\
\hline & \multicolumn{2}{|c|}{2019} & \multicolumn{2}{|c|}{2018} & \multicolumn{2}{|c|}{2019} & \multicolumn{2}{|c|}{2018} & \multicolumn{2}{|c|}{2019} & \multicolumn{2}{|c|}{2018} \\
\hline & Number & $\%$ & Number & $\%$ & Number & $\%$ & Number & $\%$ & Number & $\%$ & Number & $\%$ \\
\hline Inter RAO & 124 & 96.8 & 125 & 97.6 & 2 & 1.6 & 2 & 1.6 & 2 & 1.6 & 1 & 0.8 \\
\hline Enel Russia & 120 & 93.8 & 120 & 93.8 & 5 & 3.9 & 5 & 3.9 & 3 & 2.3 & 3 & 2.3 \\
\hline TGC-1 & 81 & 63.3 & 89 & 69.4 & 27 & 21.1 & 37 & 28.0 & 20 & 15.6 & 2 & 1.6 \\
\hline RusHydro & 123 & 96.1 & 123 & 96.1 & 3 & 2.3 & 2 & 1.6 & 2 & 1.6 & 3 & 2.3 \\
\hline Unipro & 102 & 79.7 & 98 & 76.5 & 16 & 12.5 & 18 & 14.1 & 10 & 7.8 & 12 & 9.4 \\
\hline WGC-2 & 81 & 63.3 & 84 & 65.6 & 26 & 20.3 & 20 & 15.6 & 21 & 16.4 & 24 & 18.8 \\
\hline Mosenergo & 78 & 61.0 & 62 & 48.4 & 30 & 23.4 & 56 & 43.8 & 20 & 15.6 & 10 & 7.8 \\
\hline Quadra & 76 & 59.4 & 75 & 58.6 & 22 & 17.2 & 22 & 17.2 & 30 & 23.4 & 31 & 24.2 \\
\hline TGC-2 & 80 & 62.5 & 58 & 45.3 & 36 & 28.1 & 37 & 28.9 & 12 & 19.4 & 33 & 25.8 \\
\hline
\end{tabular}

board of directors in making decisions in the interests of companies and their shareholders.

- Performance of the Corporate Secretary in protecting the rights and interests of shareholders.

- Availability of a policy for the remuneration of members of the board of directors, members of executive bodies, and other key executives, ensuring their recruitment, motivation, and retention in the company, convergence of financial interests of members of the board of directors with the interests of shareholders.

- The efficiency of the risk management and internal control system.

- Completeness, relevance, and reliability of disclosed information for shareholders and investors to make informed decisions. Equal and easy access to this information.

- Observance of the rights and interests of shareholders in carrying out material corporate actions.

- The principles of the Code are presented in its seven sections. The sections contain 24 additional subsections with 79 principles of the Code under three-digit numbers («1.1.1.» or «1.2.3.», and others) and 128 evaluation criteria recommended by the Bank of Russia. Each evaluation criterion is assigned the compliance status: «complied with,» «partially complied with,» and «not complied with.» The case study of WGC-2 PJSC shows how the results of compliance with the Code criteria in 2018-2019 were obtained for each generating company (see Table 2).

Table 3 shows only the totals for the number of criteria of the Code that are «complied with,» «partially complied with,» and «not complied with» by generating company in 2018-2019 (including percentage points).

According to this Table, generating companies varied significantly in their compliance with Code principles. In 2019, the leaders in compliance were state-owned companies - Inter RAO PJSC, RusHydro PJSC, and Enel Russia PJSC (Italy). Of the 128 evaluation criteria, they met $96.8 \%, 96.1 \%$, and $93.8 \%$, respectively. At the bottom of this list were privately-owned companies TGC-2 PJSC and Quadra PJSC - that adhered to $62.5 \%$ and $59.4 \%$ of evaluation criteria and were among the worst scoring companies. Comparative analysis of the values of leaders and the worst scoring companies in terms of the «not complied with» status of adherence to the evaluation criteria indicates that Quadra PJSC was a downright worst scoring company, with the largest gap in values. It lagged 10 to 15 times behind the leaders in compliance with the principles of the Code.

Equally significant differences were also noted in the status of individual companies' compliance with the principles of the Code. The generating companies leading in observance of these principles had the following proportions of «partially complied with» and «not complied with» criteria of those 128 ones assessed in 2019: Inter RAO PJSC - 1.6\%, 1.6\%; Enel Russia PJSC - 3.9\%, $2.3 \%$; and RusHydro PJSC $-2.3 \%, 1.6 \%$. The undeniably worst scoring company (Quadra PJSC) had a relative shift toward an increase in the criteria that were «not complied with» $-17.2 \%, 23.4 \%$. In other companies, the opposite changes were observed, i.e., towards a rise in the number of the criteria that were «partially complied with.» The most indicative companies in this regard were WGC-2 PJSC $28.1 \%, 9.4 \%$ and Mosenergo PJSC - 23.4\%, 15.6\% (see Table 3).

The oppositely directed changes among generating companies were observed when comparing 2018-2019 Code compliance results. Almost nothing changed in the leading companies. Unipro PJSC, Mosenergo PJSC, and TGC-2 PJSC increased the number of criteria they comply with by $3.2 \%$, $12.6 \%$, and $17.2 \%$, respectively. In the rest of the companies, the number of these criteria went down. There was an increase in the number of unmet criteria, which was mainly observed at TGC-1 PJSC and Mosenergo PJSC. This increase was largely due to a shift from criteria that were «partially complied with» to those «not complied with.» The number of criteria that were «partially complied with» decreased in these companies by $6.9 \%$ and $20.4 \%$, respectively (see Table 3 ).

Based on the analysis of the ownership structure of generating companies and their compliance with the principles of corporate governance, new opportunities for its development were formulated. 
Table 4. The evaluation criteria least complied with for sections i-ii of the code, 2019.

\begin{tabular}{|c|c|}
\hline Principles & CRITERIA FOR EVALUATING COMPLIANCE WITH THE CODE PRINCIPLES \\
\hline 1.2 .1 . & 2. Dividend policy provisions take into account consolidated financial statements. \\
\hline 1.2 .2 . & . The dividend policy contains clear indications of the circumstances for non-payment of dividends. \\
\hline 1.2 .4 . & $\begin{array}{l}\text { The Company strives to exclude the use by shareholders of other ways of obtaining profit (income) at its expense, in addition to } \\
\text { dividends and liquidation value. }\end{array}$ \\
\hline 2.3.1. & $\begin{array}{l}\text { 1. The adopted procedure for evaluating the performance of the board of directors }(\mathrm{BoD}) \text { includes an evaluation of the } \\
\text { professional qualifications of its members. }\end{array}$ \\
\hline 2.3 .3 . & $\begin{array}{l}\text { As part of the BoD's performance evaluation process during the reporting period, the board analyzes its needs with a focus on } \\
\text { professional qualifications, experience, and business skills. }\end{array}$ \\
\hline 2.3.4. & $\begin{array}{l}\text { As part of the procedure for evaluating the BoD in the reporting period, the board considers whether the number of its members } \\
\text { corresponds to the needs of the company and the interests of its shareholders. }\end{array}$ \\
\hline 2.4 .2 . & $\begin{array}{l}\text { 1. The } \mathrm{BoD} \text { forms an opinion on the independence of each candidate and submits the relevant conclusion to the shareholders. } \\
\text { 2. The } \mathrm{BoD} \text { reviews the independence of its current members, who are listed as independent directors in the annual report, at } \\
\text { least once during the reporting period. }\end{array}$ \\
\hline 2.4.3. & 1. Independent directors constitute at least one-third of the BoD. \\
\hline 2.4.4. & $\begin{array}{l}\text { Independent directors make a preliminary evaluation of material corporate actions related to a possible conflict of interests, and } \\
\text { results of such evaluation are provided to the BoD. }\end{array}$ \\
\hline 2.5.1. & 1. The BoD Chairman is independent, or a senior independent director is selected from the independent directors. \\
\hline 2.5 .2 . & As part of the procedure for evaluating the $\mathrm{BoD}$ performance in the reporting period, its Chairman performance is evaluated. \\
\hline 2.5 .3 . & $\begin{array}{l}\text { 1. The internal documents stipulate the obligation of the BoD Chairman to take measures to timely provide materials on the } \\
\text { issues on the agenda of the meetings to its members. }\end{array}$ \\
\hline 2.6 .1 . & $\begin{array}{l}\text { 3. A procedure is established to enable the BoD to obtain professional advice on matters within its competence at the Company's } \\
\text { expense. }\end{array}$ \\
\hline 2.6.3. & $\begin{array}{l}\text { 1. Individual attendance of meetings of the } \mathrm{BoD} \text { and its committees, and time to prepare for participation in them, are considered } \\
\text { part of the procedure for evaluating the } \mathrm{BoD} \text { performance in the reporting period. }\end{array}$ \\
\hline 2.8 .1 . & 1. The BoD forms an audit committee comprised solely of independent directors. \\
\hline 2.8 .2 . & $\begin{array}{l}\text { 1. The BoD establishes a remuneration committee consisting only of independent directors. } \\
\text { 2. The remuneration committee is chaired by an independent director, who is not the BoD chairman. }\end{array}$ \\
\hline 2.8 .4 . & $\begin{array}{l}\text { 1. In the reporting period, the BoD reviews the correspondence of members of its committees with the objectives of the board } \\
\text { of directors and the Company's business goals. }\end{array}$ \\
\hline 2.8.5. & $\begin{array}{l}\text { 1. BoD committees are chaired by independent directors. } \\
\text { 2. Internal documents contain provisions according to which non-members of committees may attend their meetings only when } \\
\text { invited by the Chairman of a relevant committee. }\end{array}$ \\
\hline 2.8.6. & 1. During the reporting period, the chairmen of the committees regularly report on their work to the BoD. \\
\hline 2.9 .1 . & $\begin{array}{l}\text { 1. Self-evaluation or external evaluation of the BoD performance in the reporting period involves evaluating the } \mathrm{BoD} \text {, its } \\
\text { members, and committees. } \\
\text { 2. The results of the self-evaluation or external evaluation of the } \mathrm{BoD} \text { are reviewed at its face-to-face meeting. }\end{array}$ \\
\hline 2.9 .2 . & $\begin{array}{l}\text { An external organization is engaged at least once to conduct an independent evaluation of the quality of the BoD's performance } \\
\text { during the last three reporting periods. }\end{array}$ \\
\hline
\end{tabular}

\section{NEW OPPORTUNITIES FOR THE DEVELOPMENT OF CORPORATE GOVERNANCE}

The study focused on three strands of new opportunities for the development of corporate governance in power generating companies for the benefit of investors in the foreseeable future: law.»

Strengthening compliance with international «soft

Expanding the criteria for evaluating the compliance with the Code principles

Updating the Code.

A. Strengthening compliance with international «soft law.»

Adherence of generating companies to the evaluation criteria recommended by the Bank of Russia was considered one of the possible directions of corporate governance development for the benefit of investors.

This direction is due to a significant number of the identified evaluation criteria recommended by the Bank of Russia (2019) that are least observed by the vast majority of generating companies. They were grouped into individual sections of the Code. The evaluation criteria that are least complied with for Sections I-II of the Code are shown in Table 4.

The evaluation criteria least complied with for Sections III-VII of the Code are shown in Table 5.

According to Tables 4 and 5, the vast majority of the least observed evaluation criteria at generating companies are related to the performance of their boards of directors within their delegated authority. This situation is most likely because the board lacks a decisive role in corporate governance as a body of strategic guidance and management control. After all, from a legal point of view, 
Table 5. The evaluation criteria least complied with for Sections III-VII of the Code, 2019.

\begin{tabular}{ll}
\hline \hline Principles & \multicolumn{1}{c}{ CRITERIA FOR EVALUATING COMPLIANCE WITH THE CODE PRINCIPLES } \\
\hline 4.1 .2$. & $\begin{array}{l}\text { During the reporting period, the remuneration committee reviews the remuneration policy and the practice of its implementation } \\
\text { and provides appropriate recommendations to the BoD, if necessary. }\end{array}$ \\
\hline 4.1.3. & $\begin{array}{l}\text { The remuneration policy contains transparent mechanisms for determining the size of remuneration for members of the BoD, } \\
\text { executive bodies, and other key executives and regulates all types of payments, benefits, and privileges provided to them. }\end{array}$ \\
\hline 4.2 .1$. & Fixed annual remuneration is the only monetary form of remuneration to the members of the BoD in the reporting period. \\
\hline 4.2 .2$. & $\begin{array}{l}\text { Provision and disclosure of clear rules for share ownership by the BoD members aimed to encourage long-term ownership of such } \\
\text { shares if the internal document (policy) on remuneration suggests granting them the Company's shares. }\end{array}$ \\
\hline 4.3.1. & $\begin{array}{l}\text { 2. The appropriate relationship between the fixed and variable parts of remuneration to the members of executive bodies and other } \\
\text { key executives of the Company based on the results of the evaluation of the BoD is adopted. }\end{array}$ \\
& $\begin{array}{l}\text { 3. A procedure is established to ensure the return of the performance pay, unduly received by the members of the Company's } \\
\text { executive bodies and other key executives, to the Company. }\end{array}$ \\
\hline 4.3.2. & $\begin{array}{l}\text { 1. A Long-Term Incentive Program using the Company's shares (financial instruments with such shares as the underlying asset) is } \\
\text { implemented. }\end{array}$ \\
$\begin{array}{l}\text { 2. The right to sell shares and other financial instruments in the Program does not arise earlier than three years from the moment } \\
\text { of its granting. }\end{array}$ \\
$\begin{array}{l}\text { 2. The BoD (or its Committee) reviews the issues pertinent to compliance with the information policy at least once during the } \\
\text { reporting period. }\end{array}$ \\
$\begin{array}{l}\text { 3. If there is a person that performs control of the Company, their memorandum regarding their plans for corporate governance in } \\
\text { the Company is published. }\end{array}$ \\
\hline 1. There is a procedure for independent directors to state their opinions on material corporate actions before their approval. \\
\hline 7.1.2.
\end{tabular}

every shareholder is the owner of generating company, the real power, however, belongs to the controlling shareholders.

In this regard, it is difficult not to agree with the authoritative opinion of I. Belikov (I. Belikov is the founder and head of the Russian Institute of Directors), who has considerable professional experience in this area, including membership on the boards of directors of more than 20 Russian and foreign companies of various capital structures and statuses (private, state-owned, public, nonpublic). In his opinion, only controlling shareholders seek to retain complete control over their companies. Given the high concentration of equity capital, significant non-market risks of doing business, and relatively weak legal and judicial protection, they can influence strategy development and decision-making by making the practice of current close interaction with the top executives of companies the basis of management. The top management directly and officially depends on the controlling shareholders and is more understandable to them as a partner than the board of directors. Controlling shareholders with more power than the board of directors can themselves influence the top executives, independently decide on the appointment and dismissal of CEOs and, often, top managers; set main objectives for them; and determine the size and forms of their remuneration. boards of directors are assigned the role of a formal participant in this relationship (often a mere observer) [23]. An indirect confirmation of this is the formal approach of generating companies to ensuring good corporate governance practices as identified in previous studies [26].

In this case, it seems necessary to tighten oversight of companies' compliance with international «soft law,» i.e., the «comply or explain» principle (this provision is recommended by the OECD for countries with relatively weak legal and regulatory structures). In this regard, the experience of France, also with its predominantly concentrated shareholding structure, is attractive and would probably be instrumental. This country established the HCGE (Haut Comité de Gouvernement d'Entreprise/ High Committee of Corporate Governance) to tighten oversight of compliance with international «soft law.» The Committee aims to oversee the application of the Code's recommendations, including reviewing companies' compliance reports. The HCGE has neither punitive nor judicial powers, but its very existence and the constant control it performs are powerful means of preventing violations of corporate governance best practices.

At the same time, generating companies require some revision and expansion of the evaluation criteria recommended by the Bank of Russia.

B. Expansion of the criteria for evaluating the compliance with the Code principles.

In the context of the introduction of information technologies, the criteria of the Code, not included in the recommendations of the Bank of Russia for reports «On Compliance with the Principles and Recommendations of the Corporate Governance Code,» are relevant. They are identified by further analysis and are listed under threedigit numbers below under the corresponding principles of the Code. Additional criteria are in italics.

1.1.5. Each shareholder shall be able to freely exercise the right to vote most easily and conveniently for them. 
- Systems are created to enable shareholders to vote electronically on the Internet by filling out a voting ballot electronically, for example, through a personal account on the Company's website.

2.3.2. The members of the board of directors shall be elected through a transparent procedure allowing shareholders to obtain information about candidates sufficient to form an idea of their personal and professional qualities.

- A preliminary discussion by shareholders of the candidates proposed for nomination to the board of directors is arranged.

- Information on the person (group of persons) who nominated this candidate, on the nature of their relations with the Company, on their membership in the boards of directors in other legal entities, as well as the nomination of this candidate to the boards of directors or for election (appointment) to other legal entities, is disclosed. Information on the person's relations with affiliated persons and principal counterparties of the Company is given.

- Information about candidates' compliance with the requirements for independent directors is indicated.

- An Internet forum on the agenda of the General Meeting of Shareholders is organized to collect shareholders 'opinions on the candidates' compliance with the independence criteria.

2.9.1. The evaluation of the board of directors' performance shall be aimed at determining the degree of efficiency of the board, its committees, and members of the board, compliance of their work with the Company's development needs; promoting active involvement of the board in performing its duties, and identifying areas where its performance can be improved.

- A formalized procedure is developed to evaluate the performance of the board of directors as a whole, the performance of its committees, each member of the board of directors, and its Chairman.

6.1.1. The Company shall develop and adopt an information policy that ensures effective information interaction among the Company, shareholders, investors, and other stakeholders.

- $\quad$ A dedicated page is organized on the Company's official website, where it posts answers to frequently asked questions from shareholders and investors, a regularly updated calendar of corporate events, and other information useful to shareholders and investors.

6.2.2. Company is advised to avoid a formalistic approach to information disclosure and to disclose material information about its activities, even if such information is not required to be disclosed by law.

- Information on legal entities controlled by the Company, which is material to the Company, including information on their role, their primary activities, the functional relationships among the key companies in the group, and the mechanisms for ensuring accountability and control within the group, is disclosed.

- Information about related party transactions following the criteria established by International Financial Reporting Standards (date; description of the terms of the transaction; names of counterparties and how they are related; grounds on which the transaction is classified as a related party transaction; reasonableness of the transaction; the transaction amount and its percentage of assets) is disclosed.

The development of corporate governance in generating companies in the interests of investors also requires certain adjustments to the Code itself, which has not been updated since its publication.

\section{Updating the Code.}

Codes of corporate governance in global practice are regularly updated. Their new revisions were adopted in the United Kingdom [19], Austria, Denmark, and Mexico (2018), Germany [21], Belgium, and Saudi Arabia (2019), Italy [20], and France [18] (2020). The central emphasis in these revisions was mainly on improving the mechanisms of interaction between boards of directors and shareholders; achieving gender equality in the boards; strengthening oversight of the applied policy of accrual of remuneration of top management and individual remuneration of senior executives; environmental and social aspects [16]. The primary purpose of the amendments is to supplement the previously developed recommendations and more clearly define the objectives of corporate governance in the modern socio-economic context.

The Russian Code, in our opinion, needs an ESG transformation to be brought up to date. Environment, social development, and corporate governance are today's unquestionable trends that involve environmental protection, fair treatment of employees and customers, and strong corporate governance. The ESG metrics are viewed by socially conscious investors as an effective tool for managing non-financial risks to achieve long-term competitive advantages of companies and are used by them to test potential investments.

Few generating companies consider the interests of their stakeholders and combine long-term economic, environmental, and social aspects in a single development strategy, factoring in social responsibility as a direct responsibility of the state. On PwC's (PricewaterhouseCoopers is an international network of companies offering consulting and audit services) maturity scale for evaluating ESG disclosure, these companies can be categorized as «laggards» [17]. The analysis of general corporate governance practices has indicated that the information they disclose about social programs and environmental policies is not detailed or systematic. They show only selected provisions on environmental policy, occupational safety and health, social programs for employees, sponsorship, and charity. Some companies have developed vision statements to implement environmental 
policies, but the current expenditures for environmental protection, as well as construction and reconstruction of environmental protection facilities, are very low.

The following criteria are proposed to assess whether companies comply with ESG principles:

The ESG system is built into the architecture of corporate governance systems of companies.

An ESG policy is developed based on the views of a wide range of stakeholders and formulates the goals, objectives, and basic principles of the company's ESG activities.

An ESG committee or supervisor from the board of directors on these issues is established.

The authority of the ESG committee is defined, including review and coordination of issues related to ESG initiatives (preparation of development strategy, internal processes, portfolio of core projects, and others), interaction with management and external stakeholders on ESG agenda issues, control over the company's ESG work.

The qualifications and experience of ESG committee members in this area are disclosed.

ESG issues are reviewed by the board of directors regularly.

Generally accepted GRI standards and principles of international reporting are used in disclosing the ESG information (GRI stands for Global Reporting Initiative, the standards of which are recognized by the UN as the main universal tool of corporate reporting, reflecting the economic, environmental and social performance of the company).

An independent auditor is engaged to verify the accuracy of ESG disclosures.

ESG metrics are developed.

ESG issues are included in the overall risk management system.

Remuneration of top management of companies is formed following the objectives set with respect to ESG and the timing of their accomplishment.

Non-financial metrics tied to the remuneration of senior executives of companies are defined.

Internal documents of companies are updated in connection with the ESG application.

It is worth noting that the legislation cannot timely and promptly respond to changes in corporate governance practices since it takes a considerable amount of time to introduce such changes. In this regard, the updates proposed for the Code can be made by generating companies in their internal documents, primarily in their Corporate Governance Codes. Advanced Russian companies are an example of this. In particular, Sberbank PJSC implements ESG principles in its corporate practice [22].

\section{CONCLUSION}

The study has revealed a high concentration of ownership and the growing presence of the state in it. There is a significant number of criteria for evaluating compliance with the Code principles, which are not observed by an overwhelming majority of generating companies. New opportunities for the development of corporate governance in the interests of investors have been elucidated. They are related to strengthening compliance with international «soft law,» expanding the criteria for evaluating compliance with the principles of the Code, as well as its ESG transformation. These opportunities will allow a fresh look at the prospects for improving corporate governance in generating companies: for owners - when meeting the criteria for evaluating compliance with its principles and updating internal documents; for investors when making more informed decisions to form a portfolio of effective assets.

\section{ACKNOWLEDGMENT}

The research was carried out under State Assignment Project (No. FWEU-2021-0001) of the Fundamental Research Program of the Russian Federation 2021-2030.

\section{REFERENCES}

[1] OECD (2016). Principles of corporate governance G20/OECD, OECD Publishing, Paris. Available: http://dx.doi.org/10.1787/9789264252035-ru. Accessed on: Jul. 27, 2021. (in Russian)

[2] Corporate Governance Code. Regulations and up-todate information of the Central Bank of the Russian Federation, Bank of Russia Bulletin, no. 40 (1518), pp. 1-63, 2014. (in Russian)

[3] Report on the compliance of Inter RAO PJSC with the principles and recommendations of the Corporate Governance Code. Available: https://www.interrao. ru/upload/InterRAO_AR19_RUS.pdf. Accessed on: Jul. 27, 2021. (in Russian)

[4] Report on compliance with the principles and recommendations of the Code of Corporate Governance recommended by the Bank of Russia Letter No. 06-52/2463 of 10.04.2014 «On the Code of Corporate Governance.» Available: https:// www.quadra.ru/upload/filials_doc/Annual_reports/ Annual_Report_by_2019_rus.pdf. Accessed on: Jul. 27, 2021. (in Russian)

[5] Report on compliance of Mosenergo PJSC with the principles and recommendations of the Corporate Governance Code. Available: https://mosenergo. gazprom.ru/d/textpage/f9/249/ar_mosenergo_2019. pdf. Accessed on: May 06, 2021. (in Russian)

[6] Report on compliance of PJSC «OGK-2» with the principles and recommendations of the Corporate Governance Code. Available: https://www.ogk2.ru/ upload/iblock/723/7233342317a2f94e48ad21d485fd 599b.pdf. Accessed on: May 20, 2021. (in Russian)

[7] Information on compliance of RusHydro PJSC with the Russian Corporate Governance Code. Available: http://www.rushydro.ru/upload/iblock/891/Knigaprilozhenij.pdf. Accessed on: May 07, 2021. (in Russian) 
[8] Report on the compliance of PJSC «TGC-1» with the principles and recommendations of the Corporate Governance Code. Available: https://www.tgc1.ru/ fileadmin/ir/reports/annual/2019/go_tgk-1_2019.pdf. Accessed on: May 10, 2021. (in Russian)

[9] Report on compliance of JSC «TGK-2» with the principles and recommendations of the Corporate Governance Code. Available: https://tgc-2.ru/upload/ iblock/502/areport_2019.pdf. Accessed on: May 12, 2021. (in Russian)

[10] Information on compliance of Enel Russia PJSC with the principles and recommendations of the Corporate Governance Code. Available: https://www.enelrussia. $\mathrm{ru} /$ content/dam/enel-ru/documents/ru/investors/ annual/Enel_Annual_report-2019-web-rus.pdf. Accessed on: May 05, 2021. (in Russian)

[11] Report on compliance of Unipro PJSC with the principles and recommendations of the Corporate Governance Code. Available: https://www.unipro. energy/shareholders/disclosure/annual_reports/. Accessed on: May 14, 2021. (in Russian)

[12] The State Duma passed in the second reading a bill that would allow Fortum to gain control over Unipro. Available: http://www.bigpowernews.ru/print/96942. phtml. Accessed on: Feb. 17, 2021. (in Russian)

[13] GEH is interested in buying the assets of Lukoil and Quadra. Available: http://www.bigpowernews.ru/ print/96737.phtml. Accessed on: Feb. 03, 2021. (in Russian)

[14] There are currently no negotiations on the merger of GEH and $\mathrm{T}$ Plus. Available: http://www. bigpowernews.ru/print/96736.phtml. Accessed on: Feb. 03, 2021. (in Russian)

[15] Roundtable «New Trends in Corporate Governance Practices in France and Russia.» Available: https:// nccg.ru/deyatelnost/kruglye-stoly.html. Accessed on: Mar. 09, 2021. (in Russian)

[16] National report on corporate governance (Vol. XII). Moscow, Russia, 2020, 304 p. Available: https:// nccg.ru/nacionalnyj-doklad-po-korporativnomuupravleniyu/572.html. Accessed on: Jan. 29, 2021. (in Russian)

[17] Oversight of ESG issues: a guide for directors. Available: https://www.pwc.ru/ru/publications/ collection/esg-guidebook-russian.pdf. Accessed on: May 28, 2021. (in Russian)

[18] Christophe Huet, «Corporate governance in France: Main provisions of the AFEP-MEDEF Code as amended on January 30, 2020.» Available: https:// nccg.ru/assets/files/issledovaniya/k.ue.-ku-vo-francii. pdf. Accessed on: Mar. 09, 2021. (in Russian)

[19] The UK Corporate Governance Code. Available: https://www.frc.org.uk/getattachment/88bd8c4550ea-4841-95b0-d2f4f48069a2/2018-UK-CorporateGovernance-Code-FINAL.PDF. Accessed on: Mar. $12,2021$.

[20] Italian Corporate Governance Code. Available: https:// www.borsaitaliana.it/comitato-corporate-governance/ codice/2020-eng.en.pdf. Accessed on: Mar. 22, 2021.

[21] German Corporate Governance Code. Available: https://www.dcgk.de//files/dcgk/usercontent/en/ download/code/191216_German_Corporate_ Governance_Code.pdf. Accessed on: Apr. 02, 2021.

[22] Corporate Governance Code of Sberbank PJSC. Available: https:/www.sberbank.com/common/ $\mathrm{img} /$ uploaded/files/pdf/normative_docs/code_of corporate_governance_of_sberbank_ru.pdf. Accessed on: Jun. 02, 2021. (in Russian)

[23] I. Belikov, Board of directors: a new approach. Moscow, Russia: RIPOL Klassik, 2019, 580 p. (in Russian)

[24] S. Guriev, O. Lazareva, A. Rachinsky, S. Tsukhlo, Corporate Governance in Russian Firms. Moscow, Russia: Institute for the Economy in Transition, 2004, 92 p. (in Russian)

[25] G. I. Sheveleva, «Who owns generating assets in the Russian electric power industry and how?» ECO, no. 6. pp. 102-114, 2017. (in Russian)

[26] G. I. Sheveleva, «Additional risks of Investment in the Russian electric power industry,» Proceedings of RAS, Power Engineering, no. 1, pp. 39-53, 2021. DOI: 10.31857/S0002331021010131. (in Russian)

[27] N. I. Voropai, Expansion planning of electric power systems: methodology, models, methods, their use. Novosibirsk, Russia: Nauka, 2015, 448 p. (in Russian)

[28] L. S. Ruzhanskaya, «The state and change of strategic aspects of the corporate governance in the Russian companies,» Vestnik NSU. Series: Social and Economic Science, vol. 10, no. 1, pp. 3-16, 2010. (in Russian)

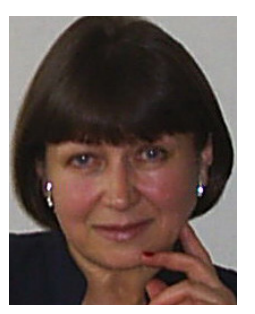

Galina I. Sheveleva graduated from Novosibirsk State University in 1978. She holds a Ph.D. degree in Economics. She is a senior researcher at Melentiev Energy Systems Institute SB RAS. Her main research interests are development, simulation and optimization of electric power systems; improvement in corporate governance in the Russian electric power industry in the interests of investors. 